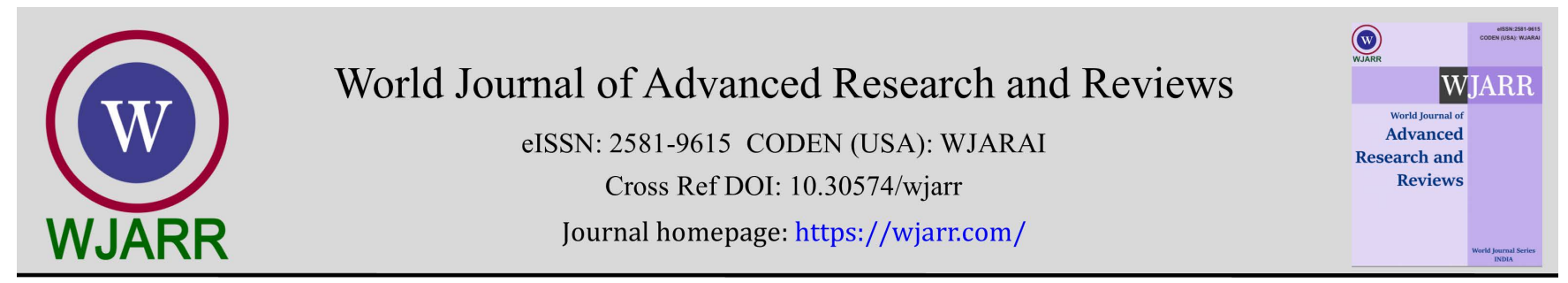

(RESEARCH ARTICLE)

Check for updates

\title{
Comparative toxicity of abamectin and nano-derived form on land snail, Helix aspersa in attributing to cytotoxicity and biochemical alterations
}

\author{
Khaled Yassin Abdel-Halim ${ }^{1,}{ }^{*}$, Safaa Ramadan Osman ${ }^{1}$, Heba Mohamed El-Danasoury ${ }^{2}$ and Gihan Fathy Aly ${ }^{3}$ \\ ${ }^{1}$ Mammalian \& Aquatic Toxicology Department, Central Agricultural Pesticides Laboratory (CAPL), Agricultural \\ Research Center (ARC), 12618-Dokki, Giza, Egypt. \\ 2 Department of Plant Protection, Faculty of Agriculture, Suez Canal University, Ismailia, Egypt. \\ ${ }^{3}$ Central Agricultural Pesticides Laboratory (CAPL), Agricultural Research Center (ARC), Sabahia, Alexandria, Egypt.
}

World Journal of Advanced Research and Reviews, 2021, 10(01), 296-311

Publication history: Received on 10 March 2021; revised on 15 April 2021; accepted on 17 April 2021

Article DOI: https://doi.org/10.30574/wjarr.2021.10.1.0140

\begin{abstract}
The comparative toxic effect of Vertimec ${ }^{\circledR}$ 1.8\% EC, Fast Max Super ${ }^{\circledR}$ 8.4\% SC and nano-derived form of abamectin (ABM) (1\% nano-emulsion) as a dermal contact for $48 \mathrm{~h}$ against land snail, Helix aspersa was evaluated at laboratorial trail. Acute toxicity values $\left(\mathrm{LD}_{50}\right)$ were $6.45,11.97$, and $45.95 \mu \mathrm{g}$ snail ${ }^{-1}$ for nano-derived form of ABM, Fast Max Super ${ }^{\circledR}$ and Vertimec ${ }^{\circledR}$, respectively. Nano-derived form exhibited the highest toxic effects (1.86 and 7.12-folds), respect to Fast Max Super ${ }^{\circledR}$ and Vertimec ${ }^{\circledR}$. Sublethal doses: $1 / 10$ and 1/100 LD50s of the examined compounds were applied to evaluate some biochemical alterations e.g. acetylcholinesterase (AChE), malondialdhyde (MDA), lactate dehydrogenase (LDH), glutathione-S-transferase (GST), acid phosphatase (ACP), alkaline phosphatase (ALP), alanine aminotransferase (ALT), and aspartate aminotransferase (AST), respectively, in haemolymph and digestive glands homogenates. The all treatments significantly decreased AChE activity in ganglia homogenate, respect to control group (untreated). All treatments exhibited MDA level and LDH activity greater than the control in both haemolymph and digestive gland. This concept recognizes the cytotoxic effect of ABM on gastropods. Significant declines in GST, ACP, and ALP activities were exhibited in homogenate of digestive gland for the all treatments. However, AST/ALT activities exhibited increase greater than untreated group. These findings may explain the role of these doses of ABM for dysfunction in organs of $H$. aspersa. Thus, prepared nano-emulsion was more potent toxic on land snails. However, H. aspersa is considered a useful tool to assess ecotoxicological impact of pesticides.
\end{abstract}

Keywords: Abamectin; Nano-emulsion; Land snail; Biochemical alterations; Cytotoxicity

\footnotetext{
* Corresponding author: Khaled Yassin Abdel-Halim

Mammalian \& Aquatic Toxicology Department, Central Agricultural Pesticides Laboratory (CAPL), Agricultural Research Center (ARC), 12618-Dokki, Giza, Egypt.
} 


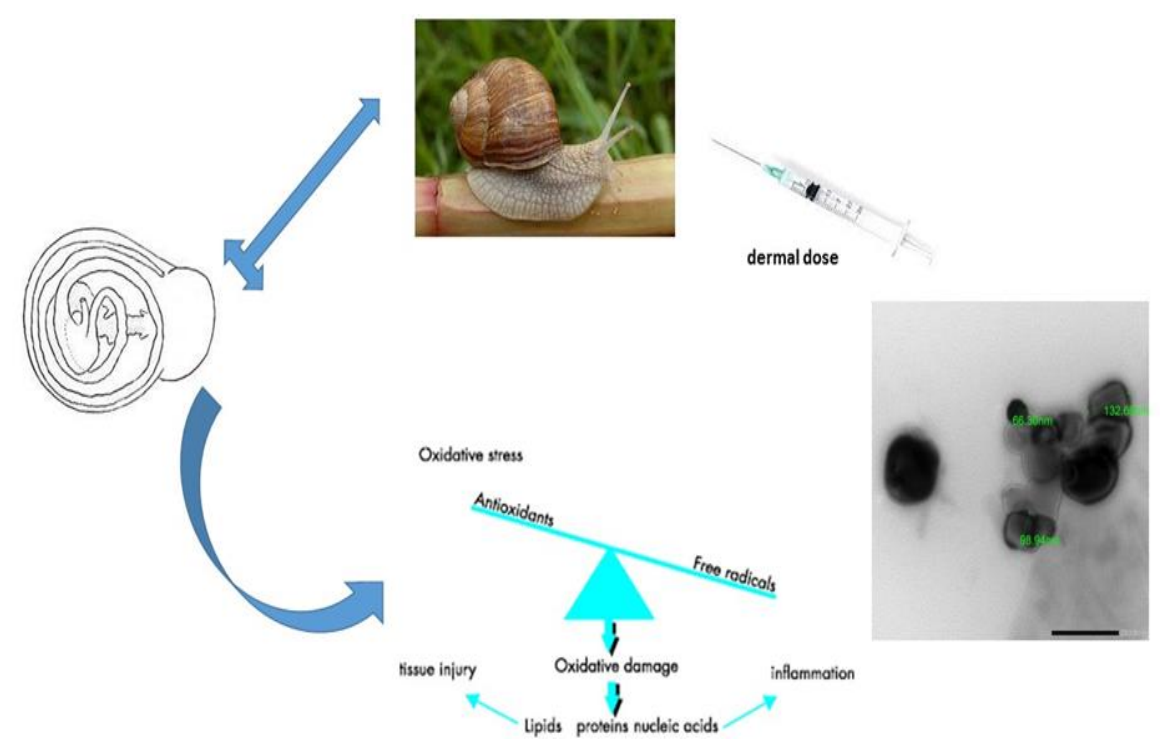

\section{Introduction}

The terrestrial snails become an economic serious pest in Egypt. They cause serious economic damage, especially in horticulture and ornamental plants [1]. The garden snail Helix aspersa (Müller) is a terrestrial gastropod mollusk, fits to helicid family (Helicidae), known as European brown snail, and dispersed in the world, especially the Mediterranean region. Also, it is used as a bio-indicator for toxicant pollution [2-4].

Recently, nanotechnology has a promising area of research in dependence on particles with special properties of size and morphology than the primary matrix. Nanoparticles (NPs) have a size in range of 1-100 nm, and increased surface area leading to the enhancement of their biological activity. However, there are many challenges in field of NPs synthesis e.g. vital need to develop non-toxic, cost effective and environmentally safe method matching with high yields. Nanomaterials have roles to enhance agricultural production providing nano-porous materials with slow release and efficient dosage of pesticides and fertilizers suitable for pest management. Nanoparticles (NPs) have remarkable characteristics (chemical, physical and biological) compared to larger particle of bulk material. For example, metallic NPs have unique catalytic activity for removal of both organic and inorganic contaminants. Using nanotechnological methods in crop protection is still in the early stages for various agricultural purposes such as development of the nanoformulations of pesticides, fungicides and herbicides used in the agricultural sector. Similarly, NPs help in gene transfer which acts as ideal tool to assess crops and plants resistant to pathogens and pests. Nanomaterials (NMs) can be used as a carrier for the agrochemicals or used as biopesticides or biofertilizers [5-6].

Abamectin (ABM) is a compartment of large ring lactone disaccharide compounds and the natural ferment product of the soil dwelling actinomycete Streptomyces avermitilis [7]. The main target of ABM is believed to affect the gammaamino butyric acid (GABA) system of animal cells [8], in which the GABA receptor is responsible for regulating the neutral basal tone [9]. Abamectin (ABM) consists of avermectin BIa, and avermectin BIb, where they are macrocyclic lactones extracted from the fermentation process of soil bacteria, S. avermitilis. It is a nerve poison used as an insecticide, acaricide, nematicide, and a veterinary antihelmintic [10]. This group stimulates the gamma-amino butyric acid (GABA) at nerve endings, and inhibits both nerve to nerve and nerve to muscle communication. The affected pest becomes paralyzed, stops feeding and dies after few days. Abamectin is broken down quickly in the soil via photodegradation at the soil surface and microbial degradation in dark, aerobic conditions. Its half-life is about 1 week on an unshaded soil surface and about two weeks to two months underneath the soil surface [11].

Snails represent a major proportion of the invertebrate biomass and are used as suitable organisms for environmental bio-monitoring assessment. Most research trails demonstrated the use of glutathione-S-transferase (GST), catalase (CAT), superoxide dismutase (SOD), glutathione peroxidase (GPx), and lipid peroxidation (LPO) in snail exposed to various toxicants and their implication in the environmental monitoring programs [12]. Thus, it provides sensitive biochemical markers for exposure and toxicity in the environmental monitoring. Among antioxidant parameters e.g. SOD, CAT, GST, GPx and LPO are extensively studied [2, 13-14]. Recently, antioxidant enzymes and the contents of malondialdehyde (MDA) have been used as biomarkers of pollutants that generate oxidative stress in aquatic animals [15-16]. Huang et al. (2019) [17] found that, ABM exposure to the Chinese Mitten Crab, Eriocheir sinensis caused significant decreases in antioxidants e.g. SOD, CAT and total antioxidant capacity (T-AOC) with dose-and time- 
dependent responses. Meanwhile, levels of MDA and carbonyl protein (CP) significantly increased. GST belongs to the phase II detoxication enzyme of animal liver and plays an important role in metabolizing and detoxication of chemicals [18-19]. Acetylcholinesterase (AChE) is an important enzyme that plays a crucial role in catalyzes the hydrolysis of the acetylcholine (ACh) neurotransmitter to maintain the normal conduct of nerve impulses [20]. Now, a lot of reports have approved that $\mathrm{AChE}$ is the main target of organophosphate and carbamate pesticides and it can be used as an important biomarker of pesticide toxicity to snails [21-22].

The present study aims to indicate if the ABM besides the NPs formulation of pesticide exposure alerts the activities of $\mathrm{AChE}$, and other biochemical quantifications in haemolymph, digestive gland and ganglia homogenates of snail $H$. aspersa.

\section{Material and methods}

\subsection{Chemicals}

Tested pesticides: Vertimec ${ }^{\circledR}$ 1.8\% EC and technical ABM 98.0\% were obtained from Syngenta Company for Agrochemicals. Fast Max Super ${ }^{\circledR}$ 8.4\% SC was obtained from Zhejang Qianjiang Biochemical Company, Ltd-China. The chemicals: potassium phosphate mono and dibase salts, trichloroacetic acid (TCA), hydrochloric acid ( $\mathrm{HCl}$ ), Tris $\mathrm{HCl}$, and sodium chloride $(\mathrm{NaCl})$ were obtained from J.T. Baker Chemical Co., Philipsburg, N.J. 08865. Acetylthiocholine iodide (ASChI), 5, 5'-dithiobis (2-nitrobenzoic acid) (DTNB), sodium pyruvate, $\alpha$-nicotinamide adenine dinucleotide (NADH), 1-Chloro, 2-4 dinitrobenzene (CDNB), glutathione (GSH; reduced form), and bovine serum albumin (BSA) were supplied by Sigma Chem. Company, P.O box 14508 St., Louis, Mo 63178 USA.

\subsection{Tested animals}

Land snail, H. aspersa was selected for experimental treatments. Healthy individuals weighing $3.0 \pm 0.7 \mathrm{~g}$ were collected from some gardens in Ismailia governorate, Egypt. The individuals were maintained for $14 \mathrm{~d}$ in wood aerated cages $\left(40 \times 40 \times 40 \mathrm{~cm} ; 100\right.$ individuals each) under laboratory conditions $\left(25 \pm 2{ }^{\circ} \mathrm{C} ; 63 \pm 2 \%\right.$ relative humidity and $12: 12 \mathrm{~h}$ light/dark). The animals were fed on lettuce leaves ad libitum. The experiments have been carried out in accordance with the European Ethical Guidelines [23].

\subsection{Nano-emulsion assessment}

\subsubsection{Preparation}

Nano-emulsion of ABM 1\% was prepared under high energy mode using sonication technique [24]. The active ingredient (a.i) was dissolved in a vegetable oil and employed to dispersion of liquid (water) with surfactant and cosurfactant to generate homogenous solution $(\mathrm{o} / \mathrm{w})$.

\subsubsection{Characterization}

Nano-derived form of ABM was employed to various storage conditions of temperature and humidity to assess emulsion stability according to ICH guidelines Q1A [25]. The prepared formulation was centrifuged at $3500 \mathrm{rpm}$ for $30 \mathrm{~min}$ to observe the phase separation. Ten $\mathrm{ml}$ of prepared formulation were diluted to $100 \mathrm{ml}$ with distilled water in graduated cylinder and employed for shaken 30 times from top to bottom continuously. At the end, the jar was allowed for 10 min and observed for oil separation: creaming, and sedimentation. On the other hand, an aliquot of the formulation was taken for heating and cooling cycle. Six cycles between refrigerator temperature of 4 and $48{ }^{\circ} \mathrm{C}$ for $48 \mathrm{hr}$ were done. So, it was employed to freeze-thaw cycle test. Three cycle were done between -21 and $25^{\circ} \mathrm{C}$.

Morphology and structure of the prepared nano-form were determined by Transmission Electron Microscopy (TEM) (JOEL 1400 Plus, Japan) at filament at $80 \mathrm{Kev}$ to observe the form and size of it. So, an aliquot of the formulation was diluted with deionized water $(1 / 100 \mathrm{v} / \mathrm{v})$, sonicated for enough time, drop of the diluted solution deposited on the film grid, dried and observed [26]. A combination of bright-field imaging at increased magnification with diffraction modes was used for optimal visualization.

Either conventional or nano-form of ABM were achieved on Fourier Transform Infrared (FTIR) instrument (TENSOR 27 Bucker, Germany-FTIR L203/1 2887). The observation was in a range from 4000 to $400 \mathrm{~cm}^{-1}$. The run was conducted with sensitivity range 50 and absolute threshold level 6.00 . 


\subsection{Acute toxicity}

The contact toxicity of the examined pesticides against snail, H. aspersa was carried out by using topical application method to determine the median lethal and the sub-lethal doses [27-28]. The tested concentrations of Vertimec ${ }^{\circledR}$, Fast Max Super ${ }^{\circledR}$ and nano-ABM were 1, 2, 4, 8, 40; 1, 2, 4, 20, 40 and 1, 2, 8, 20, $40 \mu \mathrm{g}_{\text {snail }}{ }^{-1}$, respectively. Three replicates (10 individuals, each) were used for each treatment and the animals were caged in plastic boxes. The pesticides were slightly loaded on the surface of the snail body inside the shell using micropipette containing $10 \mu$ l of vehicle. All boxes were sprayed with water to provide suitable conditions for snail activity. Percentages of mortality were estimated after $48 \mathrm{~h}$ of dosage.

\subsection{Sub-acute toxicity}

Independent on acute $\mathrm{LD}_{50}$ values of the examined pesticides, sub-lethal doses; $1 / 10$ and $1 / 100 \mathrm{LD}_{50}$ with levels; 1.2 , $0.12 \mu$ snail $^{-1}$ for Vertimec ${ }^{\circledR}$; 2.6, $0.26 \mu$ snail $^{-1}$ for Fast Max Super ${ }^{\circledR}$ and 0.65 , and $0.065 \mu$ snail $^{-1}$ for nano-ABM, respectively, were used as described above in acute toxicity experiment. Control groups were injected with vehicle (as a reference group). After $48 \mathrm{~h}$ of dosage, the live animals were taken for analysis and haemolymph was collected carefully by inserting syringe under the shell from the hemocoel along the right side of the head. The fluid was withdrawn in anticoagulant's vails and stored at $-20^{\circ} \mathrm{C}$ until used. Then, the animals were dissected to remove digestive glands and ganglia and stored as described above.

\subsection{Biochemical quantifications}

\subsubsection{Sample preparation}

One g of ganglia gland or digestive gland was homogenized in potassium phosphate buffer pH $6.5(1 / 10 \mathrm{w} / \mathrm{v})$ using mechanical polytron for $15 \mathrm{~s}$. The samples were centrifuged at $5000 \mathrm{rpm}$ for $10 \mathrm{~min}$. An aliquot of haemolymph was diluted with buffer $(1 / 10 \mathrm{v} / \mathrm{v})$. The supernatant of ganglia gland was used for AChE activity. However, supernatant of digestive gland was used for acid (ACP) and alkaline phosphatase (ALP), alanine aminotransferase (ALT), aspartate aminotransferase (AST) and GST. The homogenate was used for lactate dehydrogenase (LDH), MDA quantifications. The diluted haemolymph was used for quantifications as above.

\subsubsection{AChE}

The enzymatic activities were determined by using acetylthiocholine iodide (ASChI) as a substrate. The optical density of the developed yellow colour was recorded after $10 \mathrm{~min}$ against blank, which contained the entire reagent, expect the substrate at $412 \mathrm{~nm}$. The activity was calculated as $\mu \mathrm{M}$ of substrate hydrolysed per mg protein per min [29].

\subsection{3. $M D A$}

The barbituric acid reactive substances (TBARS) were used as an index of lipid peroxidation according to Rice-Evans et al. (1991) [30]. TBARS was determined by spectrophotometric quantification of MDA content in tissues. An aliquot (250 $\mu \mathrm{l}$ ) of tissue homogenate was mixed with $1 \mathrm{ml}$ of $15 \%$ (w/v) trichloroacetic acid (TCA) in $25 \mathrm{mM} \mathrm{HCl}$ and $2 \mathrm{ml}$ of $0.37 \%$ $(\mathrm{w} / \mathrm{v})$ thiobarbituric acid (TBA). The samples were boiled for $10 \mathrm{~min}$, quickly cooled, and immediately centrifuged at $5000 \mathrm{rpm}$ for $5 \mathrm{~min}$. The absorbance was determined at $535 \mathrm{~nm}$. MDA was quantified using an extinction coefficient of $156 \mathrm{mM}^{-1}$ and its concentration was expressed as $\mu \mathrm{M} \mathrm{g}^{-1}$ tissue.

\subsection{4. $L D H$}

An aliquot $(100 \mu \mathrm{l})$ of tissue homogenate was added to $1 \mathrm{ml}$ of working solution prepared by mixing 4 volumes of $(80$ $\mathrm{mM}$ Tris buffer $\mathrm{pH} 7.4$, sodium pyruvate $1.6 \mathrm{mM}$, and $200 \mathrm{mM} \mathrm{NaCl}$ ) with one volume of $\alpha$-nicotinamide adenine dinucleotide (NADH) $(240 \mu \mathrm{M})$. The change of absorbance was recorded every min at $340 \mathrm{~nm}$ for $3 \mathrm{~min}$. The enzyme activity was expressed as $\mathrm{U} \mathrm{L}^{-1}[31]$.

\subsubsection{GST}

The activity was determined by spectrophotometric method of Habig and Jakoby (1981) [32] by using 1-chloro, 2-4 dinitrobenzene (CDNB). Enzyme source was mixed with $500 \mu \mathrm{l}$ of potassium phosphate buffer (50 mM; pH 6.5). Incubation was done at $25^{\circ} \mathrm{C}$ for $5 \mathrm{~min}$, followed by adding of $100 \mu \mathrm{l}$ of $0.2 \mathrm{M}$ CDNB and $150 \mu \mathrm{l}$ of $10 \mathrm{mM}$ reduced glutathione (GSH). After $1 \mathrm{~min}$, the change of absorbance was recorded every $30 \mathrm{sec}$ for $6 \mathrm{~min}$ at $340 \mathrm{~nm}$. The enzyme activity was expressed as $\mathrm{nM} \mathrm{mg}^{-1} \mathrm{~min}^{-1}$. 


\subsection{6. $A C P$}

The enzyme activity was measured by using specific kits (Bio Diagnostic Co., Germany). Absorbance of the sample and standard against the blank were recorded at $510 \mathrm{~nm}$. The activity was expressed as $\mathrm{U} \mathrm{L}^{-1}$ [33].

\subsection{7. $A L P$}

The enzyme activity was measured by using phenyl phosphate as a substrate (N.S. Bio-Tec., kits, UK). So, the complex colour of $P$-nitrophenyl phosphate was measured at $405 \mathrm{~nm}$ against the blank. The activity was expressed as $\mathrm{U} \mathrm{L}^{-1}$ [34].

\subsection{8. $A S T / A L T$}

The enzyme activities were measured according to the method of Gello et al. (1985) [35] by using specific kits (Bio system Kits, Spain). The activity was expressed as $\mathrm{U} \mathrm{L}^{-1}$.

\subsubsection{Protein content}

Protein level was determined according to the method of Lowry et al. (1951) [36]. The intensity of the developed blue colour was measured at $750 \mathrm{~nm}$ against the blank. Bovine serum albumin (BSA) was used as a standard.

\subsection{Statistical analysis}

$\mathrm{LD}_{50}$ values were expressed as $\mu \mathrm{g}$ snail ${ }^{-1}$ with confidence limit (CL) and slope for the examined pesticides which computed using probit analysis [37]. All data presented as mean \pm SE were subjected to analysis of variance (ANOVA) and means were compared to significance by Student-Newman Keuls at the probability of 0.05 [38]

\section{Results}

\subsection{Characterization of nano-abamectin}

The prepared nano-emulsion was stable during freeze-thaw cycle's storage. No Creaming or floating phases were made up. Also, no separated phase was formed after centrifugation process. TEM image showed that, NPs of ABM appeared as spherical shapes, and the size was mainly in the range $(65-132 \mathrm{~nm})$. The above results demonstrated that, this method could effectively construct the compound as a nano-emulsion (Fig. 1). On the other hand, Fig. 2 illustrates FTIR patterns of conventional and nano-form of ABM, where the typical absorption peaks at $1742 \mathrm{~cm}^{-1}$ for $\mathrm{C}=0,3423 \mathrm{~cm}^{-1}$ for $\mathrm{OH}$, and $1618 \mathrm{~cm}^{-1}$ for benzene skeleton vibration which appeared in the spectra of ABM. Regarding nano-form, 1742 and $1092 \mathrm{~cm}^{-1}$ are attributed to $\mathrm{C}=\mathrm{O}$ and $\mathrm{C}-\mathrm{O}-\mathrm{C}$ stretching vibration peaks. The broad peak at $3567 \mathrm{~cm}^{-1}$ may be attributed for $\mathrm{C}=0$ group of the used co-surfactant (polymer).

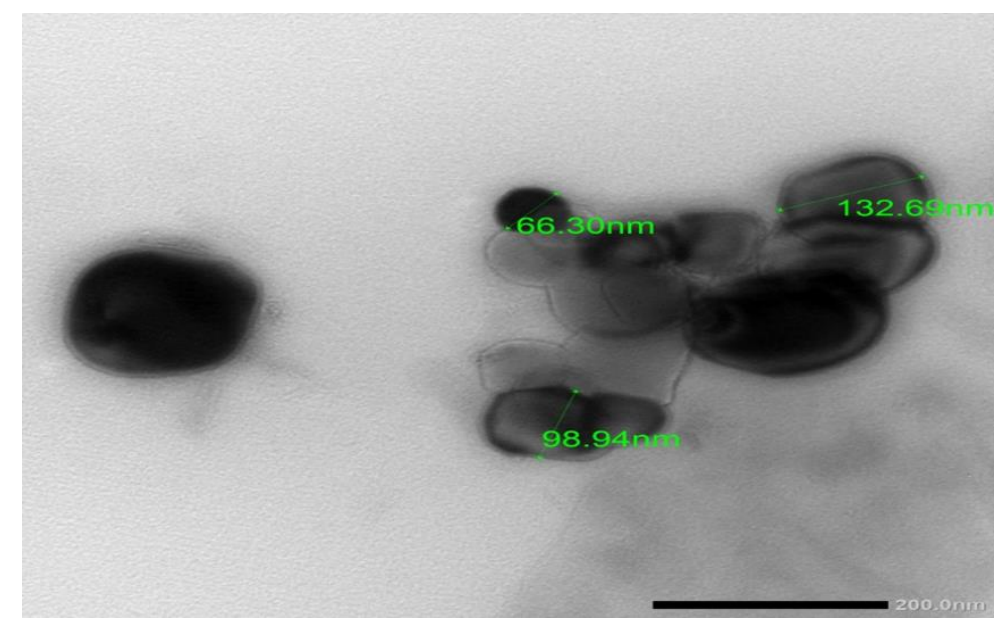

Figure 1 Electron photograph of prepared nano-emulsion of abamectin $1 \%$ a.i. visualized at $30000 \mathrm{X}$. 


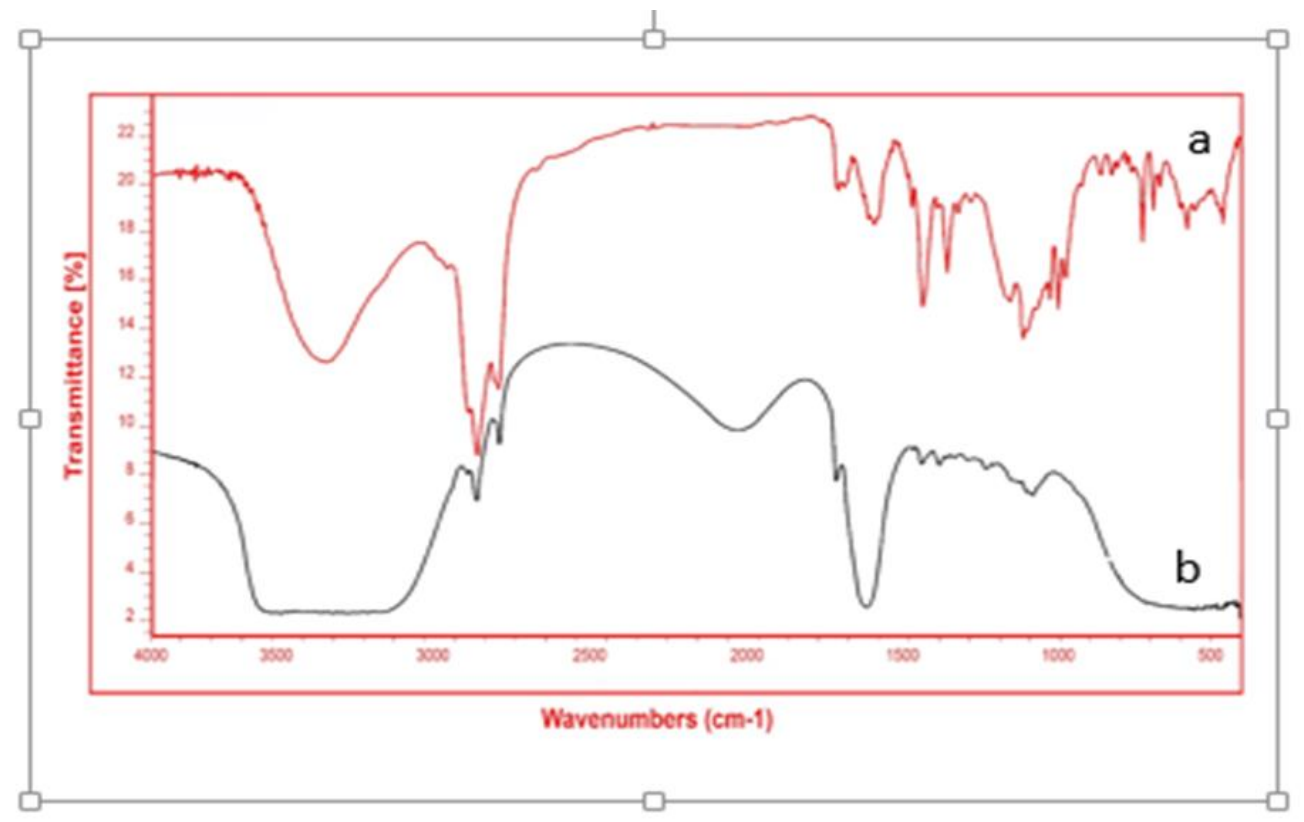

Figure 2 FTIR pattern of insecticides (a) Vertimec and (b) prepared nano-emulsion of ABM $1 \%$ a.i.

\subsection{Acute toxicity}

The acute toxicities of the examined pesticides on H. aspersa are listed in Table 1. Nano-ABM exhibited the greatest toxic effect $\left(6.45 \mu \mathrm{g}\right.$ snail $\left.{ }^{-1}\right)$, followed by Fast Max $\operatorname{Super}^{\circledR}\left(11.97 \mu \mathrm{g}\right.$ snail $\left.{ }^{-1}\right)$, and Vertimec ${ }^{\circledR}\left(45.95 \mu \mathrm{g}\right.$ snail $\left.^{-1}\right)$. Compared with nano-ABM as the highest toxic, it was greater than others with 1.86 and 7.12 folds for Vertimec ${ }^{\circledR}$ and Fast Max Super ${ }^{\circledR}$.

Table 1 The relative toxicities of the examined pesticides on land snail Helix aspersa.

\begin{tabular}{|l|l|l|l|l|l|l|l|}
\hline Pesticide & $\begin{array}{l}\text { LD } \\
(\boldsymbol{\mu g} \text { snail-1) }\end{array}$ & $\begin{array}{l}\text { Lower } \\
\text { limit }\end{array}$ & $\begin{array}{l}\text { Upper } \\
\text { limit }\end{array}$ & $\begin{array}{l}\text { Index } \\
(\mathbf{\%})\end{array}$ & Folds & Slope & $\begin{array}{l}\text { LD90 } \\
(\boldsymbol{\mu g} \text { snail-1 })\end{array}$ \\
\hline Nano-ABM & 6.45 & 4.57 & 9.06 & 100 & 1 & 0.80 & 262.56 \\
\hline Vertimec $^{\circledR}$ & 11.97 & 6.75 & 52.79 & 52.88 & 1.86 & 1.18 & 144.94 \\
\hline Fast Max Super $^{\circledR}$ & 54.93 & 25.67 & 121.99 & 14.04 & 7.12 & 0.65 & 4458.81 \\
\hline
\end{tabular}

\subsection{Biochemical responses}

For biochemical quantifications, two doses $\left(1 / 10\right.$ and $1 / 100$ of $\left.\mathrm{LD}_{50}\right)$ for each pesticide were used for $48 \mathrm{~h}$ building on $\mathrm{LD}_{50}$ value.

The activity of AChE in ganglia homogenate exhibited the greatest activity $\left(0.244 \mu \mathrm{M} \mathrm{mg}^{-1} \mathrm{~min}^{-1}\right)$ for $1 / 10 \mathrm{LD}_{50}$ treatment of Vertimec ${ }^{\circledR}$, followed by $\left(0.156 \mu \mathrm{M} \mathrm{mg}^{-1} \mathrm{~min}^{-1}\right)$ for $1 / 100 \mathrm{LD}_{50}$ treatment of nano-ABM and $\left(0.104 \mu \mathrm{M} \mathrm{mg}^{-1} \mathrm{~min}^{-1}\right)$ for $1 / 100$ LD $_{50}$ treatment of Vertimec ${ }^{\circledR}$, respectively. Fast Max Super ${ }^{\circledR}$ treatments $\left(1 / 10\right.$ and $1 / 100$ LD $\left._{50}\right)$ exhibited the activities: 0.079 and $0.091 \mu \mathrm{M} \mathrm{mg}^{-1} \mathrm{~min}^{-1}$ compared with the control $\left(0.248 \mu \mathrm{M} \mathrm{mg}^{-1} \mathrm{~min}^{-1}\right)$ (Fig. 3). 


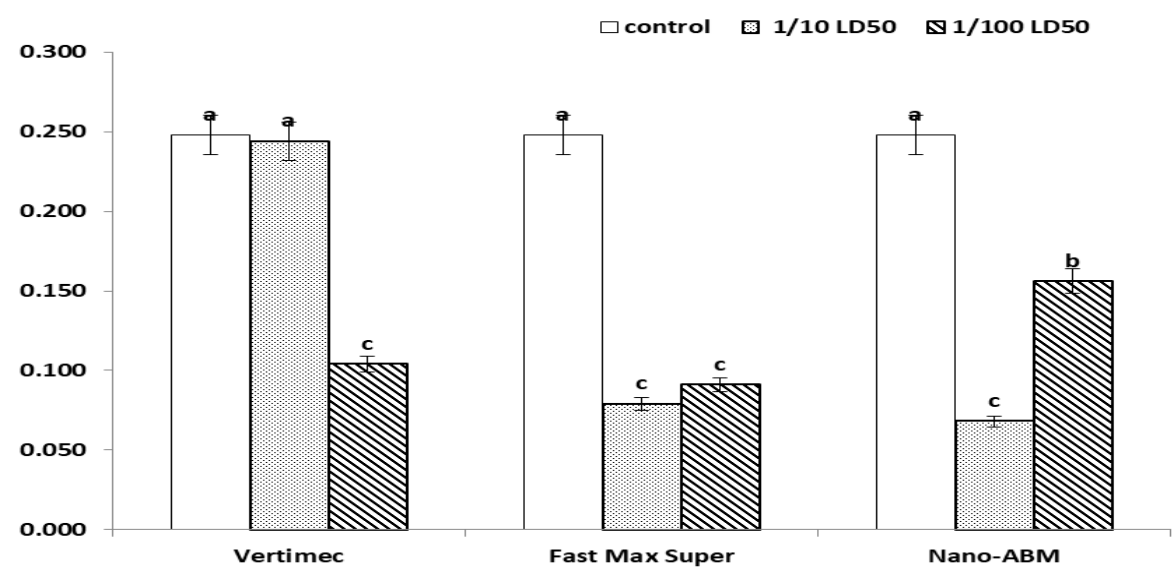

Figure 3 Activity of AChE ( $\left.\mu \mathrm{M} \mathrm{mg}{ }^{-1} \mathrm{~min}^{-1}\right)$ in ganglia homogenate of land snail, $H$. aspersa treated with two doses of different pesticides.

All treatments exhibited MDA levels greater than control in both haemolymph and digestive gland homogenate (Fig. 4). Levels of MDA in digestive gland homogenate were greater than in haemolymph. In haemolymph samples, $1 / 10$ LD 50 treatment of Fast Max Super ${ }^{\circledR}$ exhibited the greatest level $\left(1.69 \mu \mathrm{M} \mathrm{g}^{-1}\right.$ tissue), followed by $1 / 10 \mathrm{LD}_{50}$ treatment of Vertimec $^{\circledR}\left(1.61 \mu \mathrm{M} \mathrm{g}^{-1}\right.$ tissue $)$, and 1/100 LD50 treatment of Vertimec ${ }^{\circledR}\left(1.57 \mu \mathrm{M} \mathrm{g}^{-1}\right.$ tissue $)$. Treatments of nano-ABM $\left(1 / 10\right.$ and $\left.1 / 100 \mathrm{LD}_{50}\right)$ exhibited 1.23 and $1.05 \mu \mathrm{M} \mathrm{g}^{-1}$ tissue, respectively, compared with the control $\left(0.88 \mu \mathrm{M} \mathrm{g}^{-1}\right.$ tissue $)$ (Fig. 4a). Regarding digestive gland, the treatments exhibited MDA levels in the following order: Fast Max Super ${ }^{\circledR}>$ Vertimec $^{\circledR}>$ nano-ABM with values: $2.89,2.71 ; 2.66,2.51$ and $2.09,2.07 \mu \mathrm{M} \mathrm{g}^{-1}$ tissue for $1 / 10$ and $1 / 100 \mathrm{LD}_{50}$, respectively. Control group did not exceed $1.83 \mu \mathrm{M} \mathrm{g}^{-1}$ tissue (Fig. 4b).
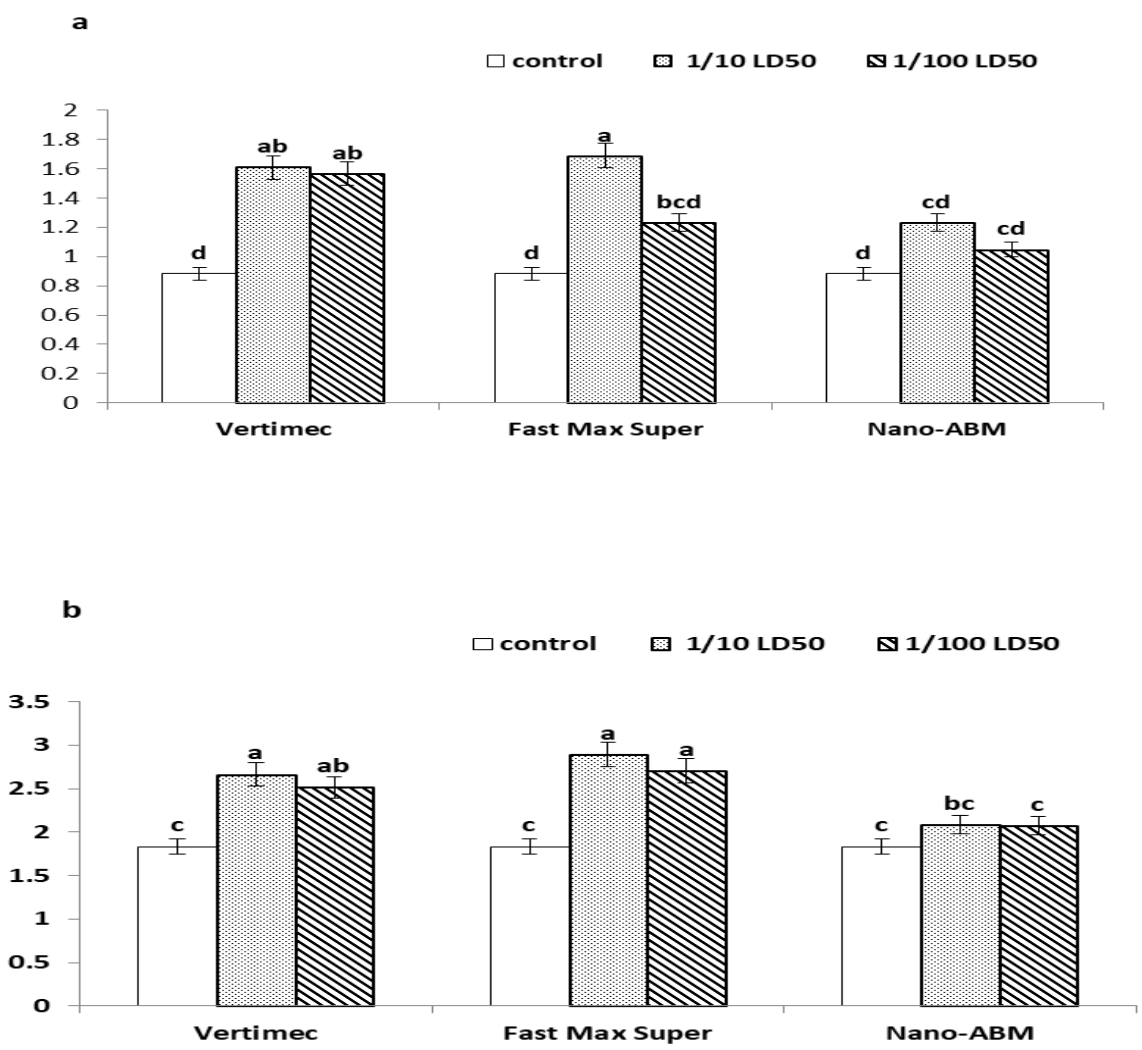

Figure 4 MDA levels ( $\mu \mathrm{M} \mathrm{g}^{-1}$ tissue) in (a) haemolymph and (b) digestive gland of land snail, H. aspersa treated with two doses of different pesticides for $48 \mathrm{~h}$. 
LDH activity is considered a good biomarker for cell damage. The all treatments exhibited enzyme activities greater than control in both haemolymph and digestive gland homogenate (Fig. 5). Activity of LDH in digestive gland homogenate was greater than in haemolymph. $1 / 10 \mathrm{LD}_{50}$ treatment of Vertimec ${ }^{\circledR}$ exhibited the greatest activity $(30.83$ $\left.\mathrm{U} \mathrm{L}^{-1}\right)$, followed by nano-ABM $\left(29.98 \mathrm{U} \mathrm{L}^{-1}\right)$, and 1/100 LD50 of nano-ABM $\left(28.78 \mathrm{U} \mathrm{L}^{-1}\right)$. No significant difference was observed in Fast Max Super ${ }^{\circledR}$ treatments. 1/100 LD ${ }_{50}$ treatment of Vertimec ${ }^{\circledR}$ exhibited the least activity $\left(23.11 \mathrm{U} \mathrm{L}^{-1}\right)$ compared with the control (10.85 U L'-1) (Fig. 5a). In case of digestive gland, 1/10 LD 50 of Fast Max Super ${ }^{\circledR}$ exhibited the greatest activity $\left(52.07 \mathrm{U} \mathrm{L}^{-1}\right)$, followed by $1 / 10 \mathrm{LD}_{50}$ treatment of Vertimec ${ }^{\circledR}\left(44.59 \mathrm{U} \mathrm{L}^{-1}\right)$, and 1/100 LD50 of Fast Max Super ${ }^{\circledR}$ (43.99 $\mathrm{U} \mathrm{L}^{-1}$ ). Nano-ABM exhibited low activities: 33.77 and $40.37 \mathrm{U} \mathrm{L}^{-1}$ for $1 / 10$ and $1 / 100 \mathrm{LD}_{50}$ treatments, compared with the control (19.50 U L-1) (Fig. 5b).

a

$\square$ control $\square 1 / 10$ LD50 $\quad \$ 1 / 100$ LD50
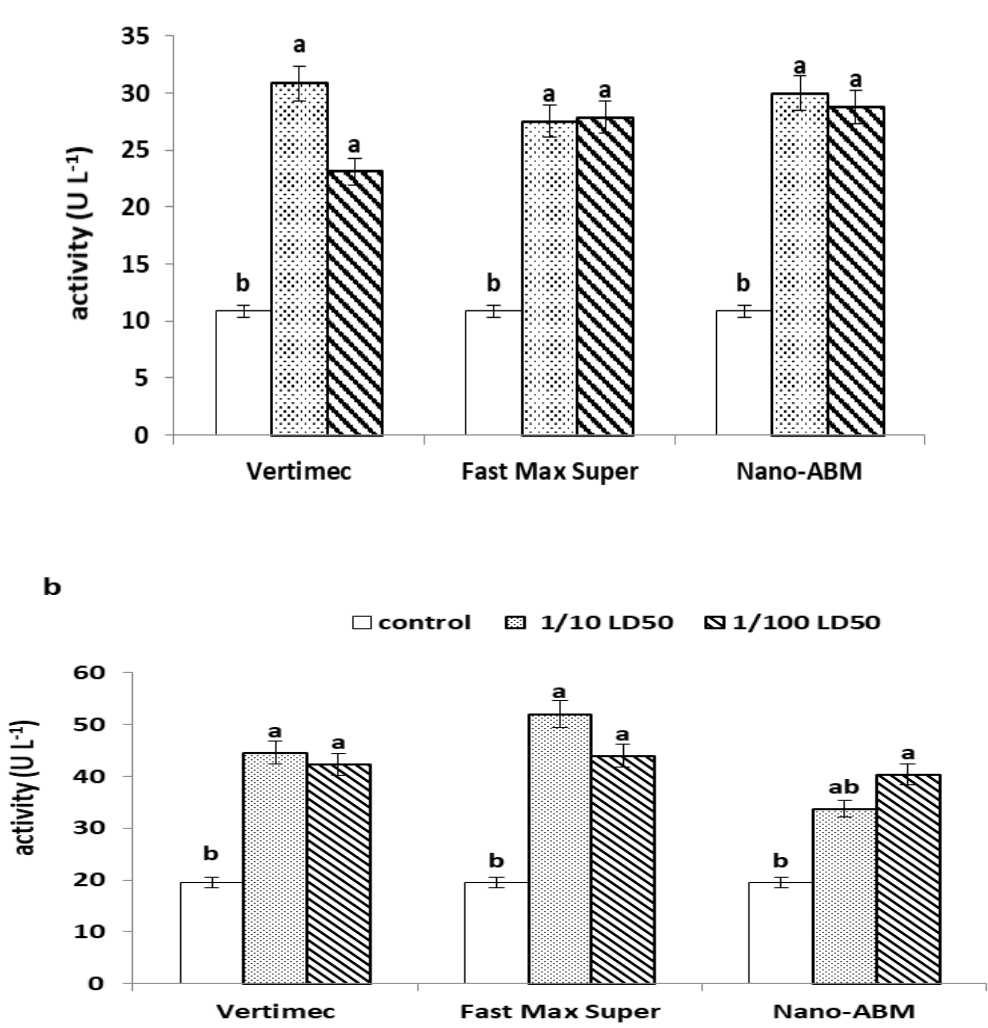

Figure 5 Activity of LDH (U L-1) in (a) haemolymph and (b) digestive gland of land snail, H. aspersa treated with two doses of different pesticides for $48 \mathrm{~h}$.

All treatments exhibited decline in GST activity in both haemolymph and digestive gland homogenate (Fig. 6). In haemolymph samples, GST activity was $2.42,0.31 ; 3.59,0.53$ and $0.94,3.72 \mu \mathrm{M} \mathrm{mg}^{-1} \mathrm{~min}^{-1}$ for $1 / 10$ and $1 / 100 \mathrm{LD}_{50}$ treatments of Vertimec ${ }^{\circledR}$, Fast Max Super ${ }^{\circledR}$ and nano-ABM, respectively (Fig. 6a). Regarding digestive gland, $1 / 10$ and 1/100 LD 50 treatments of Fast Max Super ${ }^{\circledR}$ exhibited high activities: 18.26 and $11.74 \mu \mathrm{M} \mathrm{mg}^{-1} \mathrm{~min}^{-1}$. Treatments $(1 / 10$ and 1/100 LD50) of nano-ABM exhibited activities: 7.35 and $11.27 \mu \mathrm{M} \mathrm{mg}^{-1} \mathrm{~min}^{-1}$. The same treatments of Vertimec ${ }^{\circledR}$ exhibited low activities: 3.09 and $2.28 \mu \mathrm{M} \mathrm{mg}^{-1} \mathrm{~min}^{-1}$ compared with the control $\left(20.08 \mu \mathrm{M} \mathrm{mg}^{-1} \mathrm{~min}^{-1}\right)$ (Fig. 6b). 
a

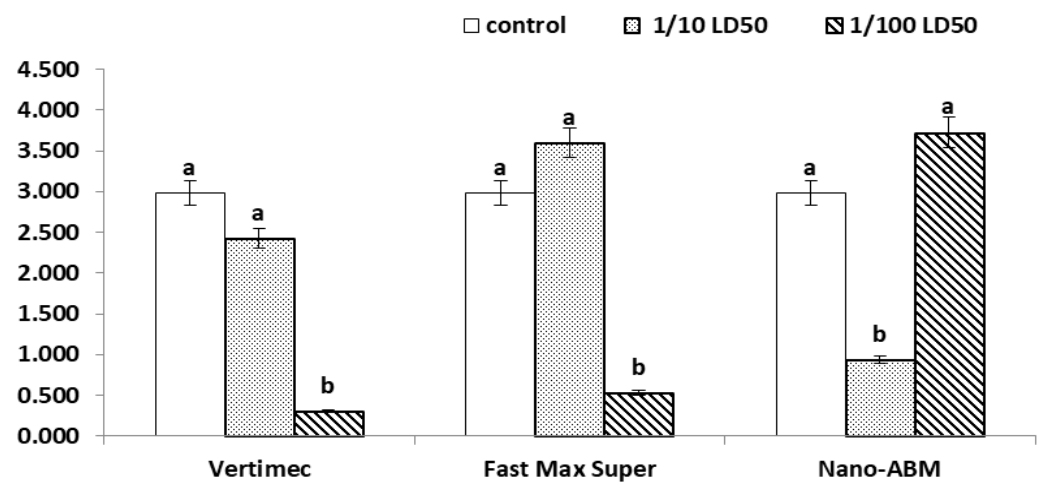

b

$\square$ control $\quad$ : 1/10 LD50 \$1/100 LD50

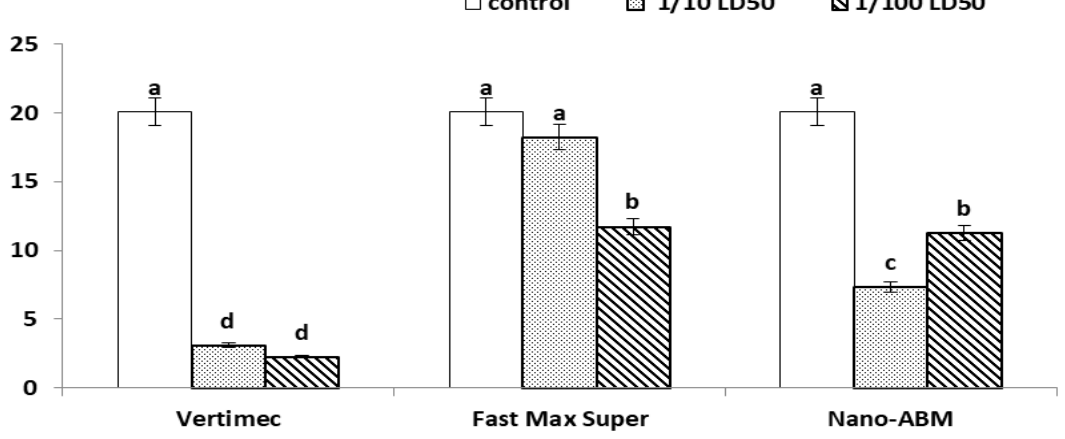

Figure 6 Activity of GST ( $\mu \mathrm{M} \mathrm{mg}{ }^{-1} \mathrm{~min}^{-1}$ ) in (a) haemolymph and (b) digestive gland of land snail, H. aspersa treated with two doses of different pesticides for $48 \mathrm{~h}$.

No significant difference was obtained in activities of ACP for the all treatments in digestive gland homogenate (Fig. 7). The activity ranged from 5.18 to $5.22 \mathrm{U} \mathrm{L}^{-1}$ for $1 / 10 \mathrm{LD} 50$ treatment of the examined pesticides, but it ranged from 5.43 to $5.31 \mathrm{U} \mathrm{L}^{-1}$ for $1 / 100 \mathrm{LD}_{50}$ treatment. The control group did not exceed $5.95 \mathrm{U} \mathrm{L}^{-1}$. In case of ALP, the activities significantly declined in comparison with control (Fig. 8). Fast Max Super ${ }^{\circledR}$ treatments $(1 / 10$ and $1 / 100$ LD 50$)$ significantly decreased enzyme activity (138.50 and $\left.165.10 \mathrm{U} \mathrm{L}^{-1}\right)$ compared with the control (374.23 $\left.\mathrm{U} \mathrm{L}^{-1}\right)$. Nano-ABM decreased activity (328.33 and $199.80 \mathrm{U} \mathrm{L}^{-1}$ ) for $1 / 10$ and $1 / 100 \mathrm{LD}_{50}$ treatments, but the same treatments of Vertimec ${ }^{\circledR}$ exhibited the activities: 318.63 and $325.42 \mathrm{U} \mathrm{L}^{-1}$.

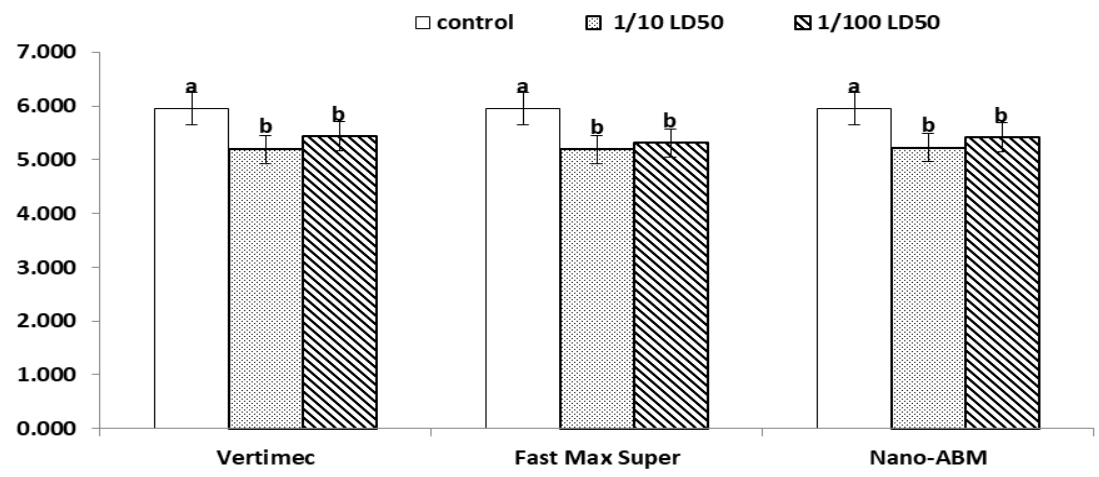

Figure 7 Activity of ACP $\left(\mathrm{U} \mathrm{L}^{-1}\right)$ in digestive gland samples of land snail, H. aspersa treated with two doses of different pesticides for $48 \mathrm{~h}$. 


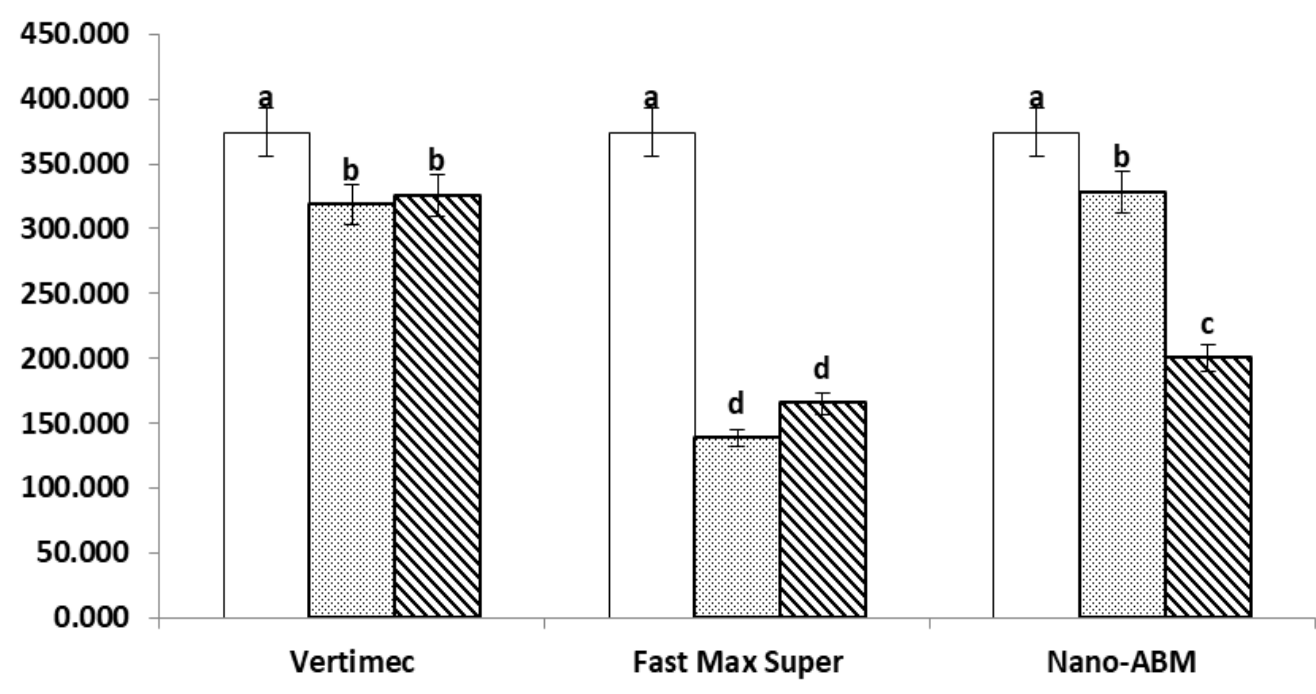

Figure 8 Activity of ALP $\left(\mathrm{U} \mathrm{L}^{-1}\right)$ in digestive gland samples of land snail, H. aspersa treated with two doses of different pesticides for $48 \mathrm{~h}$.

The activity of ALT was greater than control group in both haemolymph and digestive gland homogenate (Table 2). The activity for all treatments in digestive gland samples was greater than haemolymph. In haemolymph, $1 / 10 \mathrm{LD} 50$ treatment exhibited activity in the following order: Fast Max Super ${ }^{\circledR}>\operatorname{Vertimec}^{\circledR}>$ nano-ABM with values: $1.69,1.61$ and $1.23 \mathrm{U} \mathrm{L}^{-1}$ compared with the control $\left(0.83 \mathrm{U} \mathrm{L}^{-1}\right)$. However, $1 / 100 \mathrm{LD}_{50}$ treatment was found in the order: Vertimec ${ }^{\circledR}>$ Fast Max Super ${ }^{\circledR}>$ nano-ABM with values: $1.57,1.23$ and $1.05 \mathrm{U} \mathrm{L}^{-1}$, respectively. In digestive gland homogenate, $1 / 10$ $\mathrm{LD}_{50}$ treatment of Fast Max Super ${ }^{\circledR}$ exhibited the greatest activity $\left(2.89 \mathrm{U} \mathrm{L}^{-1}\right)$, followed by $1 / 100 \mathrm{LD}_{50}$ treatment of Fast Max Super ${ }^{\circledR}\left(2.71 \mathrm{U} \mathrm{L}^{-1}\right)$, and 1/10 LD50 treatment of Vertimec ${ }^{\circledR}\left(2.66 \mathrm{U} \mathrm{L}^{-1}\right) \cdot 1 / 100 \mathrm{LD}_{50}$ treatment of nano-ABM exhibited the least activity (2.07 $\mathrm{U} \mathrm{L}^{-1}$ ) compared with the control (1.83 $\mathrm{U} \mathrm{L}^{-1}$ ). Regarding AST activity, 1/10 LD 50 treatment was found in the following order: Vertimec ${ }^{\circledR} \geq$ Fast Max Super ${ }^{\circledR}>$ nano-ABM with values: $1.52,1.52$ and 0.93 $\mathrm{U} \mathrm{L}^{-1}$, respectively, in haemolymph samples. However, $1 / 100 \mathrm{LD}_{50}$ treatment was found in the order: nano-ABM> Vertimec ${ }^{\circledR}>$ Fast Max Super ${ }^{\circledR}$ with values: $1.40,1.17$ and $1.10 \mathrm{U} \mathrm{L}^{-1}$, respectively, compared with the control $\left(0.92 \mathrm{U}^{-}\right.$ $\left.{ }^{1}\right)$. In digestive gland homogenate, $1 / 10 \mathrm{LD} 50$ treatment of Fast Max Super ${ }^{\circledR}$ exhibited the greatest activity $\left(30.00 \mathrm{U} \mathrm{L}^{-1}\right)$, followed by $1 / 10 \mathrm{LD}_{50}$ treatment of nano-ABM $\left(26.43 \mathrm{U} \mathrm{L}^{-1}\right)$, and 1/100 LD 50 treatment of Fast Max Super ${ }^{\circledR}\left(22.53 \mathrm{U}^{-}\right.$ $\left.{ }^{1}\right)$. The treatment $\left(1 / 100 \mathrm{LD}_{50}\right.$ of Vertimec $\left.{ }^{\circledR}\right)$ exhibited the least activity $\left(7.67 \mathrm{U} \mathrm{L}^{-1}\right)$ compared with the control $(24.57$ $\left.\mathrm{U} \mathrm{L}^{-1}\right)$.

Table 2 Activities of AST and ALT enzymes ( $\left.\mathrm{U} \mathrm{L}^{-1}\right)$ in land snail, Helix aspersa treated with different pesticides for $48 \mathrm{~h}$.

\begin{tabular}{|c|c|c|c|c|c|c|c|c|c|c|c|c|}
\hline \multirow[t]{3}{*}{ Treatment } & \multicolumn{6}{|c|}{ AST } & \multicolumn{6}{|c|}{ ALT } \\
\hline & \multicolumn{3}{|c|}{ Haemolymph } & \multicolumn{3}{|c|}{ Digestive gland } & \multicolumn{3}{|c|}{ Haemolymph } & \multicolumn{3}{|c|}{ Digestive gland } \\
\hline & Vert. & $\begin{array}{c}\text { Fast } \\
\text { M. }\end{array}$ & $\begin{array}{c}\text { Nano- } \\
\text { ABM }\end{array}$ & Vert. & $\begin{array}{c}\text { Fast } \\
\text { M. }\end{array}$ & $\begin{array}{c}\text { Nano- } \\
\text { ABM }\end{array}$ & Vert. & $\begin{array}{c}\text { Fast } \\
\text { M. }\end{array}$ & $\begin{array}{l}\text { Nano- } \\
\text { ABM }\end{array}$ & Vert. & $\begin{array}{l}\text { Fast } \\
\text { M. }\end{array}$ & $\begin{array}{l}\text { Nano- } \\
\text { ABM }\end{array}$ \\
\hline $1 / 10 \mathrm{LD}_{50}$ & $\begin{array}{l}1.52 \pm \\
0.29 \mathrm{a} \\
\end{array}$ & $\begin{array}{l}1.52 \pm \\
0.29 \mathrm{a} \\
\end{array}$ & $\begin{array}{l}0.92 \pm \\
0.48 \mathrm{a} \\
\end{array}$ & $\begin{array}{c}17.25 \pm \\
0.10^{\mathrm{d}} \\
\end{array}$ & $\begin{array}{c}30.00 \pm \\
0.06^{\mathrm{a}} \\
\end{array}$ & $\begin{array}{c}26.43 \pm \\
0.06^{\mathrm{b}} \\
\end{array}$ & $\begin{array}{l}4.90 \pm \\
0.17 \mathrm{ab} \\
\end{array}$ & $\begin{array}{l}3.03 \pm \\
0.27 \mathrm{bc} \\
\end{array}$ & $\begin{array}{l}4.77 \pm \\
0.17 \mathrm{ab} \\
\end{array}$ & $\begin{array}{c}10.63 \pm \\
0.08^{c} \\
\end{array}$ & $\begin{array}{c}16.93 \pm \\
0.05^{\mathrm{a}} \\
\end{array}$ & $\begin{array}{c}18.03 \pm \\
0.04 \mathrm{a} \\
\end{array}$ \\
\hline $\begin{array}{l}1 / 100 \\
L_{50}\end{array}$ & $\begin{array}{l}1.16 \pm \\
0.38 \mathrm{a}\end{array}$ & $\begin{array}{l}1.10 \pm \\
0.41^{\mathrm{a}}\end{array}$ & $\begin{array}{l}1.40 \pm \\
0.32^{\mathrm{a}}\end{array}$ & $\begin{array}{c}7.67 \pm \\
0.22^{\mathrm{f}}\end{array}$ & $\begin{array}{c}22.53 \pm \\
0.08 \mathrm{c}\end{array}$ & $\begin{array}{c}14.19 \pm \\
0.12^{\mathrm{e}}\end{array}$ & $\begin{array}{l}3.37 \pm \\
0.24 \mathrm{bc}\end{array}$ & $\begin{array}{l}0.76 \pm \\
1.08 \mathrm{~d}\end{array}$ & $\begin{array}{l}2.43 \pm \\
0.34 \mathrm{c}\end{array}$ & $\begin{array}{l}9.33 \pm \\
0.09 c\end{array}$ & $\begin{array}{c}14.57 \pm \\
0.06^{\mathrm{d}}\end{array}$ & $\begin{array}{c}14.07 \pm \\
0.06^{b}\end{array}$ \\
\hline Control & \multicolumn{3}{|c|}{$0.92 \pm 0.48^{\mathrm{a}}$} & \multicolumn{3}{|c|}{$27.57 \pm 0.07 \mathrm{bc}$} & \multicolumn{3}{|c|}{$5.37 \pm 0.15^{\mathrm{a}}$} & \multicolumn{3}{|c|}{$16.90 \pm 0.05^{\mathrm{a}}$} \\
\hline
\end{tabular}




\section{Discussion}

Abamectin (ABM) has potential effect as anthelminthic, insecticidal, acaricidal, and nematocidal, respectively. It consists a mixture of $80 \% \mathrm{~B} 1 \mathrm{a}$ and $20 \% \mathrm{~B} 1 \mathrm{~b}$ avermectins with actual comparable biological and toxicological properties [39]. The present data of ABM toxicity on snail, $H$. aspersa are in accordance with some previous studies. There is an information of the toxic effects of ABM against land snails, where it had lethal toxic actions on the freshwater snails, Physa acuta [40], Biomphalaria alexandrina [41], land snails: Monacha contiana [42] and M. obstructa [43]. In addition, ABM was found to be more toxic on chocolate snail Eobania vermiculata [21, 44-45]. On the same species, assessment of pesticides: indoxacarb, $\mathrm{ABM}$, and spiromesifen for $24 \mathrm{~h}$ obtained that, indoxacarb was the most toxic, followed by $\mathrm{ABM}$ and spiromesifen. The $\mathrm{LC}_{50}$ values were 58.3, 83.3 and $280.9 \mathrm{ppm}$, respectively [46]. However, biopesticides: Biovar $^{\circledR}$ (Beauveria bassiana), Andros ${ }^{\circledR}$ (ABM derivative), and Radiant ${ }^{\circledR}$ (Spinosad derivative) were assayed on snail, $M$. obstructa fed on treated lettuce for 1,2 , and $5 \mathrm{~d}$. The mean values of $\mathrm{LC}_{50}$ were $5.49 \times 10^{3}$ viable spores $\mathrm{ml}^{-1}, 58.2$ and 59.6 ppm, respectively [47].

Generally, the differentiation of toxicity values for the examined pesticides on H. aspersa may be recognized to physicochemical properties, concentration and by-products or type of additives in conventional formulation recently effect on potential toxic effects and a.i uptake. The particles size or droplet size of NPs govern their stability. Surface properties of nano-formulation play a critical role in its uptake and translocation into the organism's body. There is a substantial relation between the physico-chemical properties e.g. size surface, shape of NPs dispersion and its toxicological impact on the organisms [48].

From the present findings, the pesticides caused alterations in some biochemical targets which could lead to serious metabolic and cellular damages. They affected the activities of vital enzymes in H. aspersa, where significantly imposed inhibition of AChE in ganglia homogenate. This finding was confirmed by some previous investigations. For example, Ma et al. (2014) [49] showed that, ABM-exposure to snail Physa acuta induced inhibition in AChE activity at different concentrations. On rodents, Nassar (2016) [50] showed that, ABM was able to inhibit AChE with percent $19 \%$ compared with a specific inhibitor, sumithion (83\%). Also, Nasr et al. (2016) [51] showed that, oral gavage of ABM (30 mg kg-1) for $30 \mathrm{~d}$ in rats significantly decreased AChE activity in brain and kidney organs. On the other hand, exposure to high doses of it led to cholinergic-like neurotoxic effects. In fact, use of experimental and computational studies proved evidence that, $\mathrm{ABM}$ is a potent $\left(\mathrm{IC}_{50}=10.6 \mu \mathrm{M}\right)$ inhibitor of horse serum butyryl cholinesterase $(\mathrm{BuChE})$ and interacted with the enzyme in a reversible, competitive manner predictively to block the mouth of the active-site gorge of the enzyme and to bind to several critical residues that normally bind/hydrolyze choline esters [52].

Lipids are considered a main target of oxidative stress. Lipid peroxidation (LPO) provides rise to a number secondary, highly damaging products, known to further impact of ROS production. MDA is important secondary decomposition product of polyunsaturated fatty acid (PUFA) [53]. Phospholipid of membranes in aerobic organisms is usually employed to a huge number of oxidants from exogenous sources [54-55]. For this reason, MDA concentrations can involve the rate and intensity of LPO within the organism. In the present study, the examined pesticides significantly increased MDA levels greater than control. This finding is accordance with that obtained by Bakry et al. (2013) [56], where exposure of Bulinus truncates to sublethal concentrations of herbicide, glyphosate for two weeks increased the level of MDA. Previous studies investigated increase of MDA in NPs-treated terrestrials. For example, Fahmy et al. (2014) [57] recorded a significant increase in the haemolymph and tissue of freshwater snail, B. alexandrina exposed to zinc oxide NPs (ZnONPs). Grera et al. (2012) [58] showed induction of MDA in snail, H. aspersa exposed to metallic dust. On the other hand, MDA level in digestive gland and kidney homogenates was dose-related increased at different

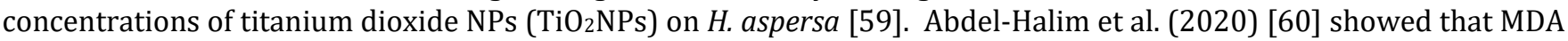
levels significantly increased in haemolymph and digestive gland of snail, M. cartusiana exposed to ZnONPs for $14 \mathrm{~d}$.

LDH is one of the cellular death biomarkers that can be measured in many cases, where its release is associated with cell and membrane damage [61-62]. In the present study, coupling of increased MDA level and LDH activity in haemolymph and digestive gland homogenate of snail, $\mathrm{H}$. aspersa is considered a good biomarker for cytotoxic effect of these pesticides.

GST enzyme involves in catalyzing the conjugation of a variety of electrophilic substrates to reduce glutathione and protect the cell against the effects of xenobiotic [63]. In addition, thiol compounds such as reduced and oxidized GSH represent the initial protective substances against pesticides and other pollutants [64]. The present study showed a significant decrease in GST activities of pesticides-treated snail compared with control group. In a previous study, ABM induced increase in GST activity in freshwater snail, $P$. acuta after 96-h exposure to some pesticides. However, MDA levels of the snail soft tissues increased in all treatments $(3.4,9.6,19.2$ and $27.4 \mu \mathrm{g} \mathrm{L}-1)$ indicating that LPO significantly occurred in comparison with the control [49]. However, increased GST activity in snails exposed to lead (Pb) 
reproduced and displayed that defense system of the animal achieved to positively respond by trying to protect itself against xenobiotic inducing toxicity [65].

Both ACP and ALP are hydrolyzed enzymes, where they are liable to remove phosphate group from some molecules e.g. nucleotide, proteins, and alkaloids [66]. The present data proved a decline in activity of theses enzymes resulting in dysfunction for digestive gland of H. aspersa.

The results of this study were also supported by that obtained by Radwan et al. (1992) [67], where some carbamate pesticides induced significant elevation in AST and ALT activities when applied against land snail, Theba pisana. In fact, the deviation of both enzyme activities out of the normal range could lead to biochemical impairment and lesions of the tissues and cellular functions. Generally, transaminase enzymes: AST and ALT are not solely located in hepatocytes, but also in many body organs. In fact, AST/ALT ratio is commonly measured as a biomarker for liver health status [68]. Also, the elevation in their activities could be due to a variety of conditions including muscle damage, intestinal and hepatic injury [69]. Similarly, Felix Wróblewski et al. (1956) [70] found that AST activity increased 20 times following acute myocardial infarctions. As documented by Sharaf et al. (2015) [71], sublethal concentrations of pesticides: diazinon, lambda-cyhalothrin and methomyl induced increases in CAT, AST, ALT, ALP activities and MDA level in tissue homogenate of M. cantiana.

Some xenobiotic e.g. pesticides are able to enhance the risk factor, reactive oxygen species (ROS) inducing injury concluded reduced gastric mucus synthesis, which is considered a potent scavenger of ROS [72]. These concepts are in accordance with that obtained in this study, where ABM in the examined forms was able to generate ROS in the selected tissues and fluid.

\section{Conclusion}

In this study, a prominent toxic effect of ABM and nano-derived form on $H$. aspersa was detected for the measured biochemical parameters in selected orangs. So, the prepared nano-ABM is critical to be used as an acaricide against harmful pests after further toxicological studies to arise its safety to human and non-target organisms. Moreover, $H$. aspersa is considered a useful tool to assess ecotoxicological impact of pesticides.

\section{Compliance with ethical standards}

\section{Acknowledgments}

The authors wish to acknowledge Staff of Electron Microscope Unit (EMU) of Alexandria University, Egypt for their help about NPs characterization.

\section{Disclosure of conflict of interest}

The authors declare that no potential conflicts of interest with respect to the research, authorship and/or publication of this article.

\section{References}

[1] Goden D. Pest slugs and snails: biology and control. Springer-Verlage, Berlin. 1983; 445.

[2] Radwan M, El-Gendy K, Gad, AB. Oxidative stress biomarkers in the digestive gland of Theba pisana exposed to heavy metal. Archives of Environmental Contaminants and Toxicology. 2010; 58: 828-835.

[3] Madjon P, Arrebola J, Madejon E, Burgos P, Lopez-Garrido R, Carcaba A, et al. The snail Theba pisana as an indicator of soil contamination by trace elements: Potential exposure for animals and humans. Journal of Science Food and Agriculture. 2013; 93: 2259-2266.

[4] Abdel-Halim KY, El-Saad AA, Talha M, Hussein A, Bakry N. Oxidative stress on land snail Helix aspersa as a sentinel organism for ecotoxicological effects of urban pollution with heavy metals. Chemosphere. 2013; 93: 1131-1138.

[5] Manimegalai G, Shanthakumar S, Sharma C. Silver nanoparticles synthesis and application in mineralization of pesticides using membrane support. International Nano Letters. 2014; 4: 105-109.

[6] Wang A, Wang Y, Sun C. Fabrication, characterization, and biological activity of avermectin nano-delivery systems with different particle sizes. Nanoscale Research Letters. 2018; 13: 2-7. 
[7] Luo I, Sun YJ, Wu YJ. Abmectin resistance in Drosophila is related to increased expression of P. glycoprotein via the dEGFR and dAKT pathways. Insect Biochemistry and Molecular Biology. 2013; 43: 627-634.

[8] Maioli MA, de Medeiros HCD, Guelf M, Trinca V, Pereira FTV, Mingatlo FE. The role of mitochondria and biotransformation in abamectin-induced cytotoxicity in isolated rat hepatocytes. Toxicology in Vitro. 2013; 27: 570-579.

[9] Turner MJ, Schaeffer JA. Mode of action of ivermectin in: Campbell WC (Ed), Ivermectin and Abamectin. Springer, New York. 1989; 73-88.

[10] Jansson RK, Dybas RA. Avermectins: Biochemical mode of action, biological activity and agricultural importance. In: I. Ishaaya, and D. Degheele, (eds) Insecticides with novel modes of action: mechanisms and application. Spr RA.inger-Verlag. New York. 1998; 152-167.

[11] ETN. Pesticide formation profiles: Abamectin Extension Toxicology Network. 1996.

[12] Bahgat J, Ingole BS, Singh N. Glutathione-S-transferase, catalase, superoxide dismutase, glutathione peroxidase, and lipid peroxidation as biomarkers of oxidative stress in snails: A review. Invertebrates Survival Journal. 2016; 13: 336-349.

[13] El-Shenawy NS, Mohammadden A, Al-Fahmie ZH. Using the enzymatic and non-enzymatic antioxidant defense system of the land snail Eobania vermiculata as biomarkers of terrestrial heavy metal pollution. Ecotoxicology and Environmental Safety. 2012; 84: 347-354.

[14] Wang X, Liu Z, Wang W, Yanz Zhang C. Assessment of toxic effects of triclosan on the terrestrial snail (Achatina fullica). Chemosphere. 2014; 108: 225-230.

[15] Zapata-Vivenes E, Nusetti O. Protection of glycolytic by metal metalothioneins from oxidative damage in the digestive gland of green lioped mussel Perna viridis. Journal of Shellfish Research. 2007; 26: 335-344.

[16] Siwela AH, Nyathi CB, Naik YS. A comparison of metal levels and antioxidant enzymes in freshwater snails, Lymnea natalensis exposed to sediment and water collected from Wright Dam and lower Mg uza Dam, Bulawayo, Zimbabwe. Ecotoxicology Environmental Safety. 2010; 73: 1728-1732.

[17] Huang K, Hong Y, Huang Z, Zhang J, Huang Q. Avermectin induces the oxidative stress, genotoxicity, and immunological responses in the Chinese Mitten Crab, Eriocheir sinensis. PLOS ONE. 2019; 14: e0225171.

[18] Dallingar R. Strategies of metal detoxification in terrestrial invertebrates In: Dallingar R, and Rainbow PS. (Eds). Ecotoxicology of metals in invertebrates. Lewis Publishers. London. 1993; 246-281.

[19] Storey KB. Oxidative stress: animal adaptations in nature. Brazilian Journal of Medical and Biological Research. 1996; 29:1715-1733.

[20] Chen A, Du D, Lin Y. Highly sensitive and selective immune-capture electrochemical assay of acetylcholinesterase activity in red blood cells, as biomarker of exposure to organophosphorus pesticides and nerve agents. Environmental Science and Technology. 2012; 46: 1828-1833.

[21] Essawy AE, Abdelmeguied NE, Radwan MA, Hamed SS, Hegazy AE. Neuropathological effect of carbamate molluscicides on the land snail, Eobania vermiculata. Cell Biology and Toxicology. 2009; 25: 275-290.

[22] Laguerre C, Sanchez-Hernandez JC, Kohler HR, Triebskorn R, Capoweiz Y, Rault M, Mazzla C. B-type esterase in the snail Xeropicta derbentina: an enzymological analysis to evaluate their use as biomarkers of pesticide exposure. Environmental Pollution. 2009; 157: 199-207.

[23] Directive 2010/63/EU. Europran Parliament and the council of the European Union. Directive 2010/63/EU of the European Parliament and of the council of 22 September 2010 on the protection of animals used for scientific purposes. Official Journal of European Union L. 2010; 276: 33-79, 2010.

[24] Gupta A, Burak EH, Alan HT, Doyle PS. Nanoemulsions: formation, properties and application. Journal of Royal Society of Chemistry. 2016; 21: 2826-2841.

[25] ICH. Stability testing of new drug substances and products, q1a (r2). In International Conference on harmonization of technical requirements for registration of pharmaceuticals for human use. Geneva, Switzerland, February. 2003.

[26] Bhatt P, Madhav S. A detailed review on nanoemulsion drug delivery system. International Journal of Pharmaceutical Sciences and Research. 2011; 2: 2482-2489. 
[27] Hussein HI, Kamel A, Abou-Zeid M, El-Sebae AH, Salah MA. Uscharin, the most potent molliscicides compound tested against land snails. Journal of Chemical Ecology. 1994; 29: 135-140.

[28] Radwan MA, Essawy AE, Abdelmeguid NE, Hamed SS, Ahmed AE. Biochemical and histochemical studies on the digestive gland of Eobania vermiculata snails treated with carbamate pesticides. Pesticides Biochemistry \& Physiology. 2008; 90: 154-167.

[29] Ellman GL, Courtney DK, Andreas V, Featherstone RM. A new and rapid colorimetric determination of acetylcholinesterase activity. Biochemical Pharmacology. 1961; 7: 88-95.

[30] Rice-Evans CA, Diplock AT, Symons NCR. Technique in Free Radical Research. Elsevier, Amsterdam. 1991.

[31] Mc Queen MJ. True Arrhenius relationships of human lactate dehydrogenase. Zeitschrift fÜr Klinische. Chemie und Klinische Biochemie. 1975; 13: 17-19.

[32] Habig WH, Jakoby WB. Glutathione-S-transferase (rat and human). Methods of Enzymology. 1981; 77: $218-231$.

[33] Kind PRN, King EJ. Estimation of plasma phosphatase by determination of hydrolysed phenol with aminoantipyrine. Journal of Clinical Pathology. 1954; 7: 322-326.

[34] Bowers GN, McComb RB. A continuous spectrophotometric method for measuring the activity of serum alkaline phosphatase. Clinical Chemistry. 1966; 12: 70-89.

[35] Gello FJ, Olivella T, Cruz-Pastor M, Arenas J, Morono R, Durban R, Gomez JA. A simple procedure for routine determination of aspartate aminotransferase and alanine aminotransferase with pyridoxol phosphate. Clinica Chimica Acta. 1985; 153: 241-247.

[36] Lowry OH, Rasebrough NJ, Farr AI, Randall RJ. Protein measurement with the folin phenol reagent. Journal of Biological Chemistry. 1951; 193: 265-275.

[37] Finney DJ. Probit analysis. 2nd ed. Cambridge University Press, UK. 1971.

[38] Cohort Software Inc. Costat User Manual, version 3. Cohort Tucson, Arizona, USA. 1985.

[39] Fisher MH, Mrozik H. The chemistry and pharmacology of avermectins. Annual Review of Pharmacology and Toxicology. 1992; 32: 537-553.

[40] Ma JG, Li XY. Acute toxicity of lambda-cyhalothrin, imidacloprid and avermectin on Physa acuta. Journal of Hydroecology. 2011; 32: 100-104.

[41] Mohamed AM, Bakry FA, Heiba FN. Molluscicidal effects of abamectin on Biomphalaria alexandrina and its infection with Schistosoma mansoni. Journal of First International Conference of Biological Sciences. 2000; 1 : 207-216.

[42] Mortada MM, Mourad AAM, Abo-Hashem AM, Keshta TMS. Land snails attacking pear fields: Efficiency of certain biocides and molluscicides against Monacha sp: land snails at Dakahlia governorate. Journal of Plant Protection and Pathology, Mansoura University. 2012; 3: 717-723.

[43] Sallam AA, Dosoky ASS, Abouelkassem S, Abd El-Rahman TMM. Toxicity of seven pesticides belonging to different chemical groups against the glassy clover snail, Monacha obstructa by using three methods of application under laboratory conditions. International Journal of Research Studies in Zoology. 2016; 2: 17-23.

[44] Abdallah EA, Abdelgalil GM, Kassem FA, Asran AA, Abou-Elnasser HS. Comparative molluscicidal activity of abamectin and methomyl against Eobania vermiculata (Müller) and Theba pisana (Müller). Journal of Plant Protection and Pathology Mansoura University. 2015; 12: 1671-1683.

[45] Hemmaid KZ, Ahmed SA, El-akhrsay FI. Ultrastructural alterations in cells of the digestive gland of Eobania vermiculata (Müller) treated with three chemical compounds. Middle East Journal of Applied Sciences. 2017; 7: 595-612.

[46] Hussein MA, El-Kasafy SH. Assessment of some new pesticides as molluscicides against the adult and eggs of chocolate banded snail, Eobania vermiculata. Bulletin of the National Research Centre. 2019; 43: 75-80.

[47] Bahy El-Din IA, Kares EA, El-Khawas MAM. Bioassay of three biopesticides against Hypera bruneipennis (Boheman) (Coleoptera: Curculionidae) and Monacha obstructa Ferussac. (Moullusca: Helicidae) in the laboratory. Annual of Agricultural Sciences Moshtohor. 2016; 54: 669-676.

[48] Cornelis G, Hund-Rinke KM, Kuhlbusch T, Van den Brink N, Nickel C. Fate and bioavailability of engineered nanoparticles in soils. Environmental Science and Technology. 2014; 44: 2720-2764. 
[49] Ma J, Zhou C, Li Y, Li X. Biochemical responses to the toxicity of the biocide abamectin on the freshwater snail Physa acuta. Ecotoxicology and Environmental Safety. 2014; 101: 31-35.

[50] Nassar AMK. Acetylcholinesterase: a universal toxicity biomarker. Journal of Agricultural and Environmental Sciences, Damanhour University. 2016; 15: 136-148.

[51] Nasr HM, El-Demerdash FM, El-Nagar WA. Neuro and renal toxicity induced by chlorpyrifos and abamectin in rats. Environmental Science and Pollution Research. 2016; 23: 1852-1859.

[52] Terali K, Dalmizrak 0, Hoti Q, Ozer N. Evaluation of the inhibitory effect of abamectin on mammalian butyryl cholinesterase: Enzyme Kinetic and molecular docking studies. Environmental Science and Health Part B. 2018; 53: 713-718.

[53] Liu H, Yang D, Yang H, Zhang W, Zhang Y, Fang Z, et al. Comparatively study of respiratory tract immune toxicity induced by three sterilization nanoparticles: Silver, Zinc oxide and titanium dioxide. Journal of Hazardous Materials. 2013; 248-249: 478-486.

[54] Furtado-Filhp OV, Polcheira C, Machado DP, Mourdo G, Hermes-Lima M. Selected oxidative stress markers in a South American crocodilian species. Comparative Biochemistry and Physiology. 2007; 146: 241-254.

[55] Monaghan P, Metacalfe NB, Torres R. Oxidative stress as a mediator of life history trade- offs: mechanisms, measurements and interpretation. Ecology Letters. 2009; 12: 75-92.

[56] Bakry, FA, El-homossany K, Abd ElAtti MS, Ismaiel SM. Alterations in the fatty acid profile, antioxidant enzymes and protein pattern of Biomophalaria alexandarina snails exposed to the pesticides diazinon and profenofos. Global Journal of Pharmacy and Pharmacology. 2013; 1: 27-36.

[57] Fahmy SR, Abdel-Ghafar F, Bakry FA, Sayed DA. Ecotoxicological effect of sublethal exposure to Zinc oxide nanoparticles on freshwater snail Biomphalaria alexandrina. Archives of Environmental Contaminants and Toxicology. 2014; 67: 192-202.

[58] Grera N, Atarlia A, Bouceuna M, Kheldi F, Berrebab H, Djebar MR. Effects of heavy metals on the snails Helix aspersa bioindicators of environmental pollution for human health. International Conference of Applied Life Sciences (ICALS 2012) Turkey, September 10-12: 2012.

[59] Khene L, Berrebbah H, Yahyaoui A, Bouarroudj T, Zouainia S, Kahli H, et al. Biomarkers of oxidative stress, lipid peroxidation and ROS production induced by TiO2 microparticles on snails Helix aspersa. Studi "Universitatis Vasile Goldis" Seria Strintele Vietii. 2017; 27: 127-133.

[60] Abdel-Halim, KY, Osman SR, Abdou GY. In vivo evaluation of oxidative stress and biochemical alterations as biomarkers in glass clover snail, Monacha cartusiana exposed to zinc oxide nanoparticles. Environmental Pollution. 2020; 257: 113-120.

[61] Osman KA. Lindane, chlorpyrifos and paraquat induced oxidative stress in female rats. Alexandria Journal of Agricultural Researches. 1999; 44: 345-355.

[62] Bakry FA, Hasheesh WS, Hamdi SAH. Biological, biochemical, and molecular parameters of Hlisoma duryi snails exposed to pesticides malathion and deltamethrin. Pesticides Biochemistry and Physiology. 2011; 101: 86-91.

[63] Ferrari A, Venturino A, Pechen de D'Angelo PM. Effects of carbonyl and azinphos-methyl on juvenile rainbow trout (Oncorhynchus mykiss) detoxifying enzyme. Pesticides Biochemistry and Physiology. 2007; 88: $134-142$.

[64] Commins I, Dixon DP, Feitag-Pohl S, Skipsey M, Edwards R. Multiple roles for plant glutathione-S-transferases in xenobiotic detoxification. Drug Metabolism Reviews. 2014; 432011: 266-280.

[65] Basopo N, Ngabaza T. Toxicological effects of chlorpyrifos and lead on the aquatic snail Helisoma duryi. Advances in Biological Chemistry. 2015; 5: 225-233.

[66] Arceci RJ, Hann IM, Smith OP. Pediatric hematology (3rd ed.). Wiley Blackwell. 2006; 763.

[67] Radwan MA, El-Wakil HB, Osman KA. Toxicity and biochemical impact of certain oxime carbamate pesticides against terrestrial snail, Theba pisana (Müller). Journal of Environmental Science and Health Part B: Pesticides, Food, Contaminants, and Agricultural Wastes. 1992; 27: 759-773.

[68] Ghouri N, Preiss D, Sattar N. Liver enzymes, nonalcoholic fatty liver disease, and incident cardiovascular disease: a narrative review and clinical perspective of prospective data. Hepatology. 2010; 52: 1156-1161.

[69] Farkas JP, Farkas P, Hyde D. Liver and gastroenterology tests. In: Basic skills in interpreting laboratory data, Lee M. (Ed.).3rd Ed. American Society of Health-System Pharmacists Inc., USA. 2004; 330-336. 
[70] Felix Wróblewski MD, George Jervis MD, John S, Ladue MD. The diagnostic, prognostic and epidemiologic significance of serum glutamic oxaloacetic transaminase (sgo-t) alterations in acute hepatitis. Annals of Internal Medicine. 1956; 45: 782-800.

[71] Sharaf HM, Abd El-Atti MS, Salama MA. Toxic effects of some pesticides on the enzymatic activities and spermatogenesis of the land snail Monacha cantiana. Journal of Bioscience and Applied Research. 2015; 1: 139146.

[72] Mitobe Y, Hiraishi H, Sasai T, Shimada T, Terano A. The effects of Asprin on antioxidant defences cultured rat gastric mucosal cells. Alimentary Pharmacology \& Therapeutics. 2000; 14: 10-17.

[73] Directive 2010/63/EU. 2010. Europran Parliament and the council of the European Union. 2010. Directive 2010/63/EU of the European Parliament and of the council of 22 September 2010 on the protection of animals used for scientific purposes. Official Journal of Eureopean Union L 276: 33-79. 